
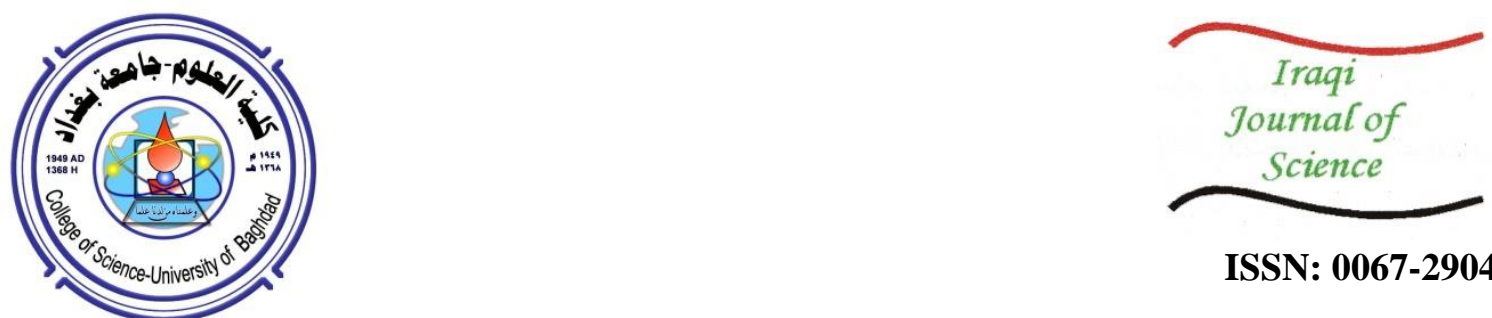

ISSN: 0067-2904

\title{
2D Seismic Reflection Study of Mishrif and Yamama Formations in East Nasiriya Area, Southern Iraq
}

\author{
Mohammed S. Faisal*, Kamal K. Ali \\ Department of Geology, College of Science, University of Baghdad, Baghdad, Iraq
}

Received: $2 / 12 / 2020 \quad$ Accepted: $18 / 1 / 2021$

\begin{abstract}
The structural division and stratigraphic estimation of the perceptible geological basin are the most important for oil and gas exploration. This study attempts to obtain subsurface geology in parts of east Nasiriya, southern Iraq using of seismic data and some adjacent well information for structural and stratigraphic interpretation. To achieve this goal, 2D seismic data in SEG-Y format were used with velocity and logging data. The seismic profile is then interpreted as a twodimensional (time domain and depth domain) contour map, which is represented as a real subsurface geology.

Reflectors from the Mishrif and Yamama Formations (Cretaceous period) were detected. According to the structural interpretation of the selected reflectors, TWT maps of the horizon were prepared, and depth maps were drawn, which show some noses structures in the study area. The seismic interpretation in this area confirmed the existence of certain stratigraphic features in the studied strata. Some distribution mounds and flat spots were also observed which similar to the characteristics of the Nasiriya oil field stratigraphic features that are the considered as hydrocarbon indicators.
\end{abstract}

Keywords: structural and stratigraphy, hydrocarbon indicators, Nasiriya oilfield, seismic reflection.

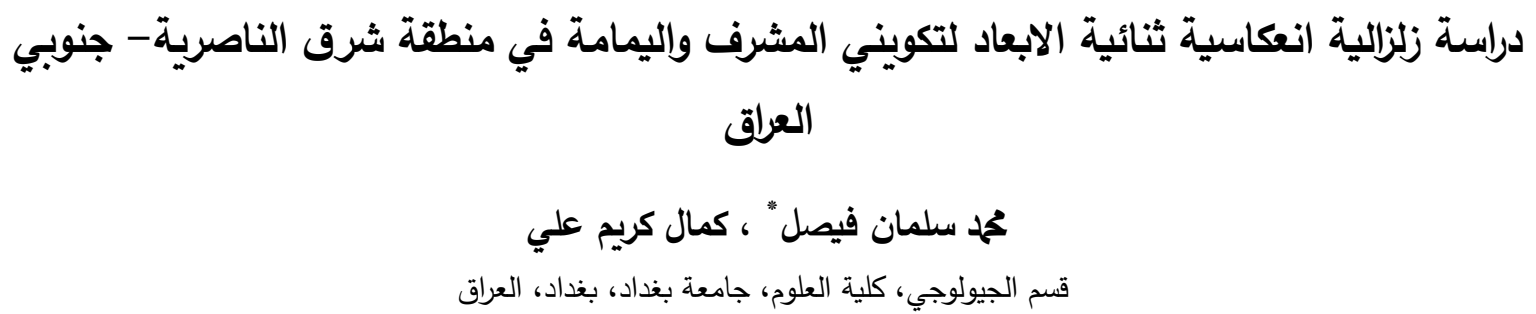

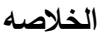

يعد تعيين الوضع التركيبي والطباقي للحوض الجيولوجي من اهم مراحل الاستكثاف عن النفط والغاز.

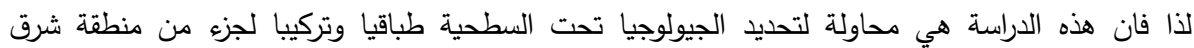

الناصرية، جنوبي العراق باستخدام المعلومات الزلزالية الانعكاسية ثنائية الابعاد. لأجل تحقيق هذه الاهداف

استخدمت بينات المسح الزلزالي ثنائية الابعاد بصيغة (SEG-Y) مع سرع وبيانات الجس البئري. تم رسم

المقطع الزلزالي للمنطقة بعد ذلك جرى تفسيره كخرائط زمنية ثنائية الابعاد ( زمني وعمقي) والتي تمثل انعكاس

الواقع الجيولوجي تحت السطحي.

*Email: mh.salman259@gmail.com 


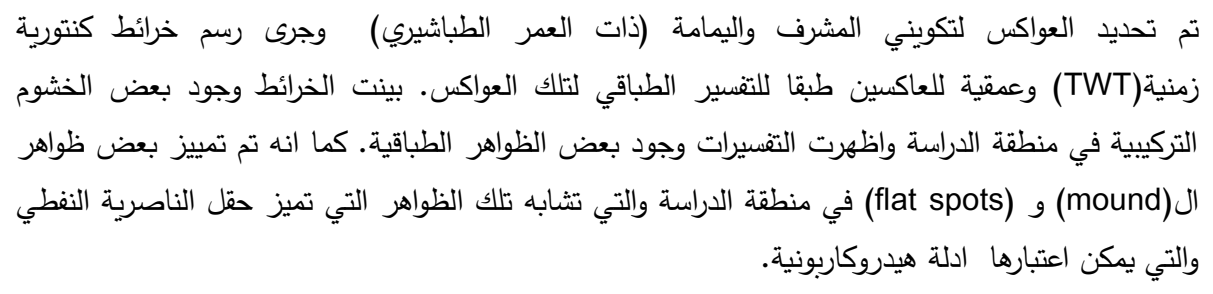

\section{Introduction}

Seismic method is the main important method of geophysical exploration, because it has deep penetration ability and high resolution, can detect the physical properties of subsurface geology. Seismic exploration plays a recognized role in eliminating many problems in subsurface geological structures, and it is increasingly important in supporting engineering geological exploration. In geophysical procedures, seismic reflection strategy can be considered as the most important technique for discovering oil and gas reservoirs[1].

Seismic interpretation manages the process of obtaining geological data from seismic information. In most cases, seismic surveys include three main steps, including: data acquisition, processing, and seismic interpretation. The reflected wave is first generated and then undergoes a processing step to form a stacked seismic section whose shape is suitable for the interpretation step of interpretation[2]. There are two fundamental parts of the seismic interpretation: Structural analysis (reflector study based on reflection time) and stratigraphic examination (or seismic stratigraphy), that is, the examination of the reflection sequence as the seismic item of the lithology identification sedimentary sequence[3].

In the term of oil economic value, Mishrif and Yamama Formations are belonged to the most important oil production reservoirs in southern Iraq and neighboring area, which are deposited during Cretaceous period. These formations are characterized by good reservoir's specifications to contain hydrocarbon [4]. The chosen study has an important location between the oil fields and it is considered as the extension for many of studies carried out by a number of researchers, where it specializes on structure and stratigraphy analysis of Mishrif and Yamama Formations.

\section{Location of the study area}

The study area is located in southern of Iraq (about: $2160 \mathrm{~km}^{2}$ ), including the Nasiriya city and extending to the east, belong to Thi-Qar province as shown in Figure-1. It lies within the Universal Transverse Mercator (WGS-84, U.T.M, Zone-38) having coordinates points: 615332.55 E $3470323.16 \mathrm{~N}, 655971.87$ E $3470323.16 \mathrm{~N}, 655971.87 \mathrm{E} 3416346.61 \mathrm{~N}$ and $615332.55 \mathrm{E}$ $3416346.6 \mathrm{~N}$. The study area is surrounded by the west Qurnah, Subba, Deima and Nasiriya oil fields from the directions of east, south, north east and west respectively.

According to the geological map of Iraq[5], the study area is located within a flat topography covered by Holocene deposits within the Quaternary Period which contain the flood plain deposits. The area characterized by marshland in the most of its southern and eastern parts. Small channels are present in the southern part and north-west in addition to the Euphrates River which intersects the area from the west and passing continuously to the south.

Agreeing with the divisions of tectonic map of Iraq [6], Iraq was divided into three tectonic provinces which trend northwest to southeast, parallel to the structures between the Eurasian plate and the Arabian plate. These provinces are the thrust region (Geosynclines), the Mesozoic unstable Shelf (Mesopotamian foredeep) and Mesozoic Stable Shelf. The map shows that the study area is flat and no structural features appear on the surface. According to the longitudinal tectonic classification of Iraq[7-8] the study area is located at the southern part of Iraq within the Mesopotamian basin of unstable shelf (Simawa-Nasiriya subzone). 


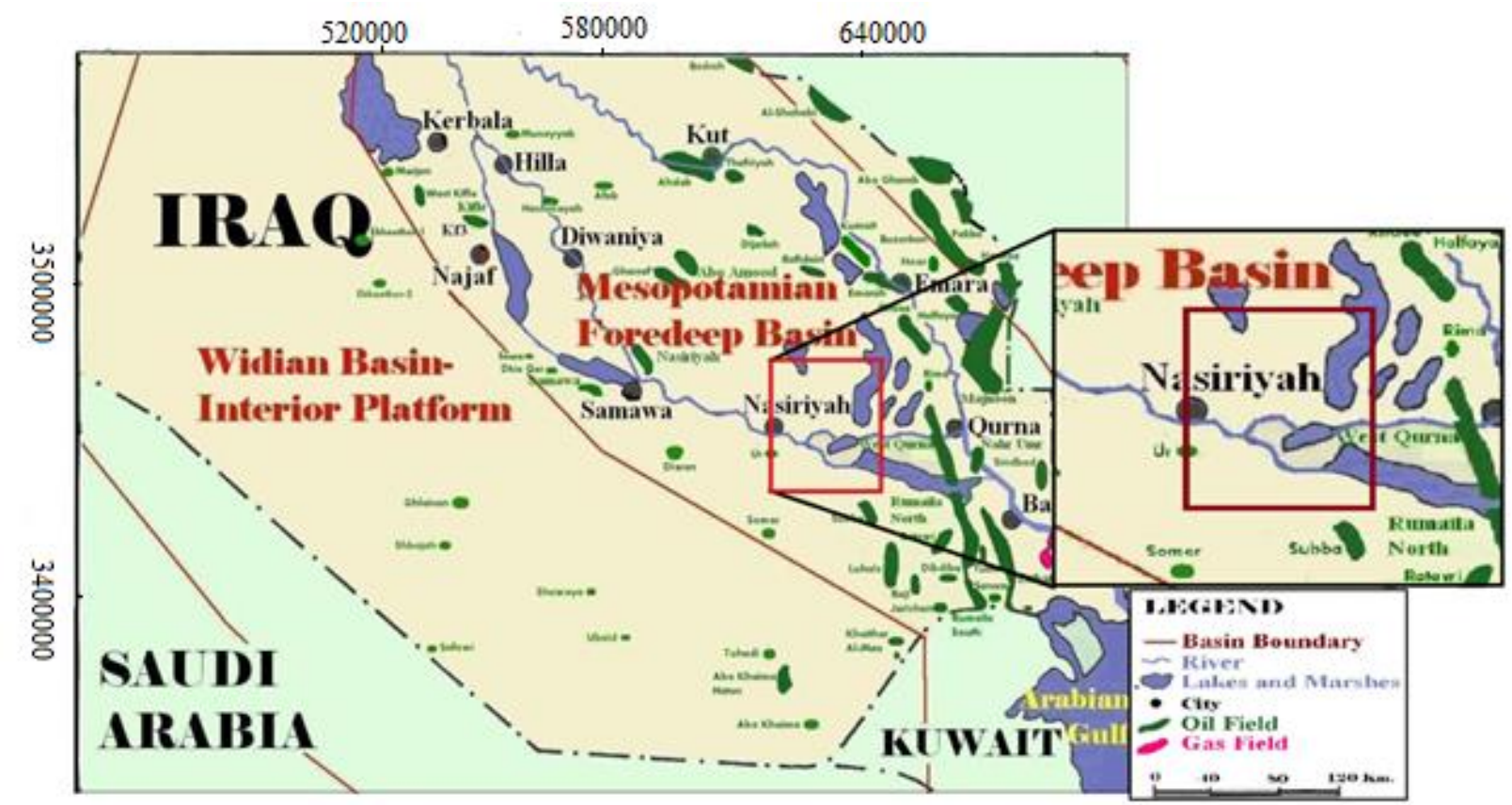

Figure 1-Location map of the study area.

\section{Materials and Methods}

The area was surveyed using 2D seismic method in(1969-1968) by geophysical French company (CGG) with coverage about (6\%) used dynamite as an energy source. In current study, the obtained seismic data has been loaded to Petrel software in SEG-Y format then base map of study area is constructed and starting the interpretation operations.

A velocity map usually uses the velocity changes along the horizontal and vertical directions on a particular profile. The map is constructed using velocity information obtained from the seismic section.

Therefore, the main purpose of seismic interpretation is to create seismic contour maps, which show the two-way time (TWT map) of the reflector acquired on the seismic section. This time (isochronous) map must be converted to a depth (iso-depth) map through the seismic time-depth conversion process. Contour maps are the most accurate representation of subsurface geology, therefore, the interpreted seismic profile and average velocity information are used to generate a twodimensional contour map of the strata of interest in the study area.

The data base includes 2D survey, because the area is still without exploration wells. So that, wells nears to the study area are used. These wells are located in the surrounding of the study area (Nasiriya and Subba oil field wells) and used to identify the reflectors to perform seismic interpretation.

The targeted formations in this study are:

1-Mishrif Formation: The Mishrif Formation is characterized by high heterogeneity and is divided into four "zones" from the bottom to the Tuuba-1 well in the Rumaila-Zubair area, namely Mi/D, C, B And A[4]. Generally, four facies can be identified in the Mishrif Formation, namely: restricted shelf, red column accumulation, open shelf and sub-basic layer. Mishrif facies are combined with each other, and the boundary is not obvious $[9,10]$. The Mishrif represents a very complex sequence defined originally as complex of detrital limestone, containing sometimes algal, rudist, and coral-reef limestone; capped by limonitic fresh water limestone. This definition was given by [11].

2-Yamama Formation: The Yamama Formation is a carbonate-dominated passes into and overlies the Sulaiy Formation. It is $400 \mathrm{~m}$ thick in the Zubair area [11-7]. The Ratawi Formation overlies Yamama Formation in conformable surface, towards the west (in the Salman Zone), where the Yamama and Ratawi formations are absent, the Zubair Formation overlies Jurassic rocks in unconformable surface[12]. The Formation is made up mainly of limestone, but some dolomitic limestone and shale have been reported. In the southwestern part of Yamama basin, some well contain anhydrite within the Yamama section [11]. 


\section{Base map construction}

25 seismic lines were used in this study area and are loaded to Petrel as 2D data in the time domain in SEG-Y format through the seismic interpretation window. This process is used to achieve the interpretation procedure on the interactive workstation. After that, construct the base map of the study area, as shown in Figure-2.

\section{Synthetic Seismogram generation}

The calibrated sonic $\log$ is multiplied by the estimated density log to calculate the acoustic impedance, and then the reflection coefficient is calculated. The deterministic wavelet is convolved with the reflection coefficient to generate a synthetic seismogram. The seismic section matches well with the synthetic seismogram(Figure-3).

\section{Velocity Survey}

A type of borehole seismic data designed to measure the propagation time from the surface to a known depth. The result of this process will be a time-depth curve, which can be used for depth-totime or time-to-depth conversion. Check-Shot survey can be used to convert acquired logging data into time, so the seismic interpretation can be confirmed or modified by correcting sonic logging and generating synthetic seismograms, thereby correlating the data with surface seismic data. The curve can be used to convert the time map section into depth sections. Figures- 4 and 5 show the check-shot records of Ns1 and Su8 wells. As mentioned before the lack of wells in study area lead us to use the wells of Nasiriya and Subba oil fields in addition to their check shot with sonic and density logs in generating the synthetic seismograms.

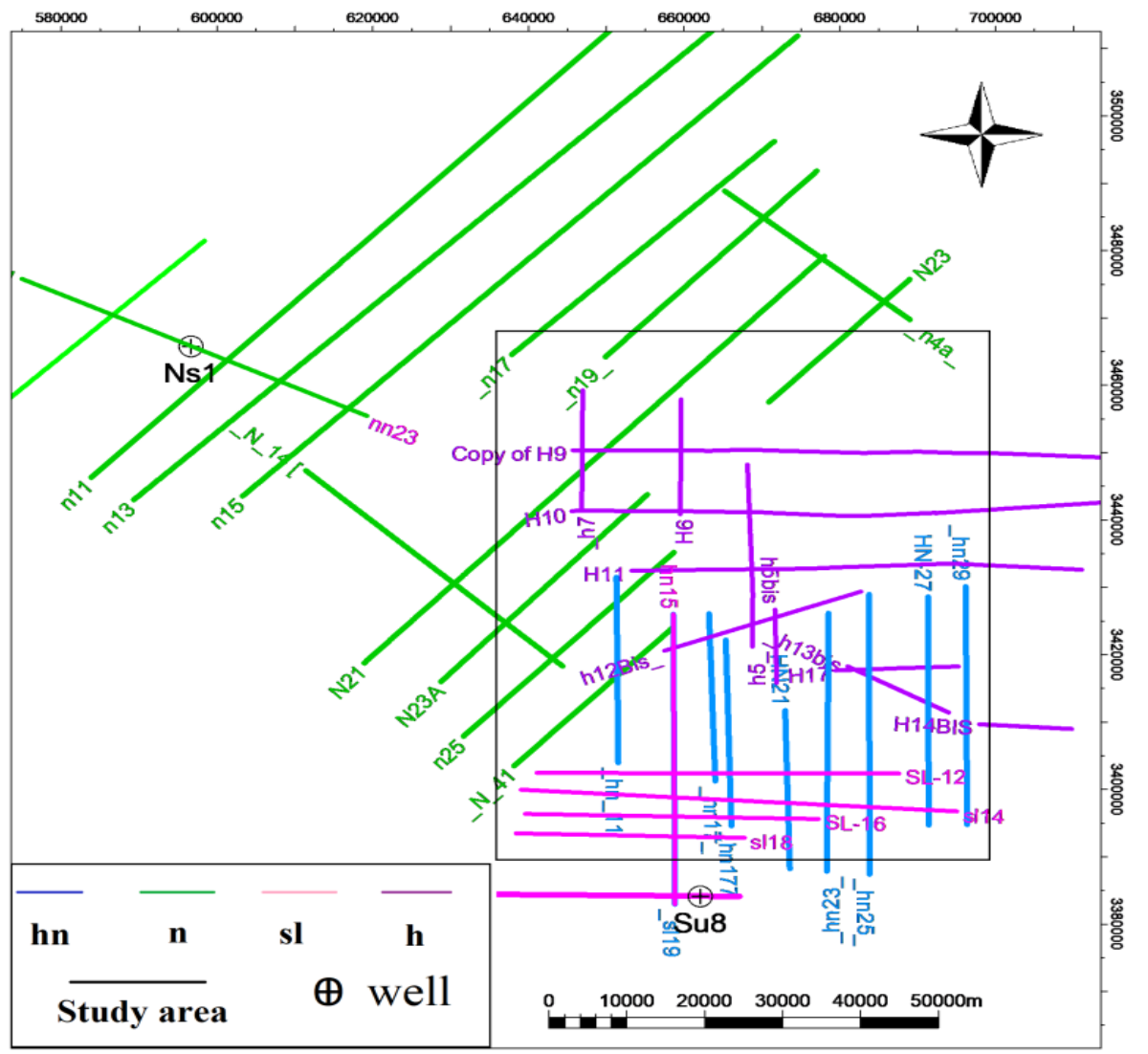

Figure 2-Base map of study area. 


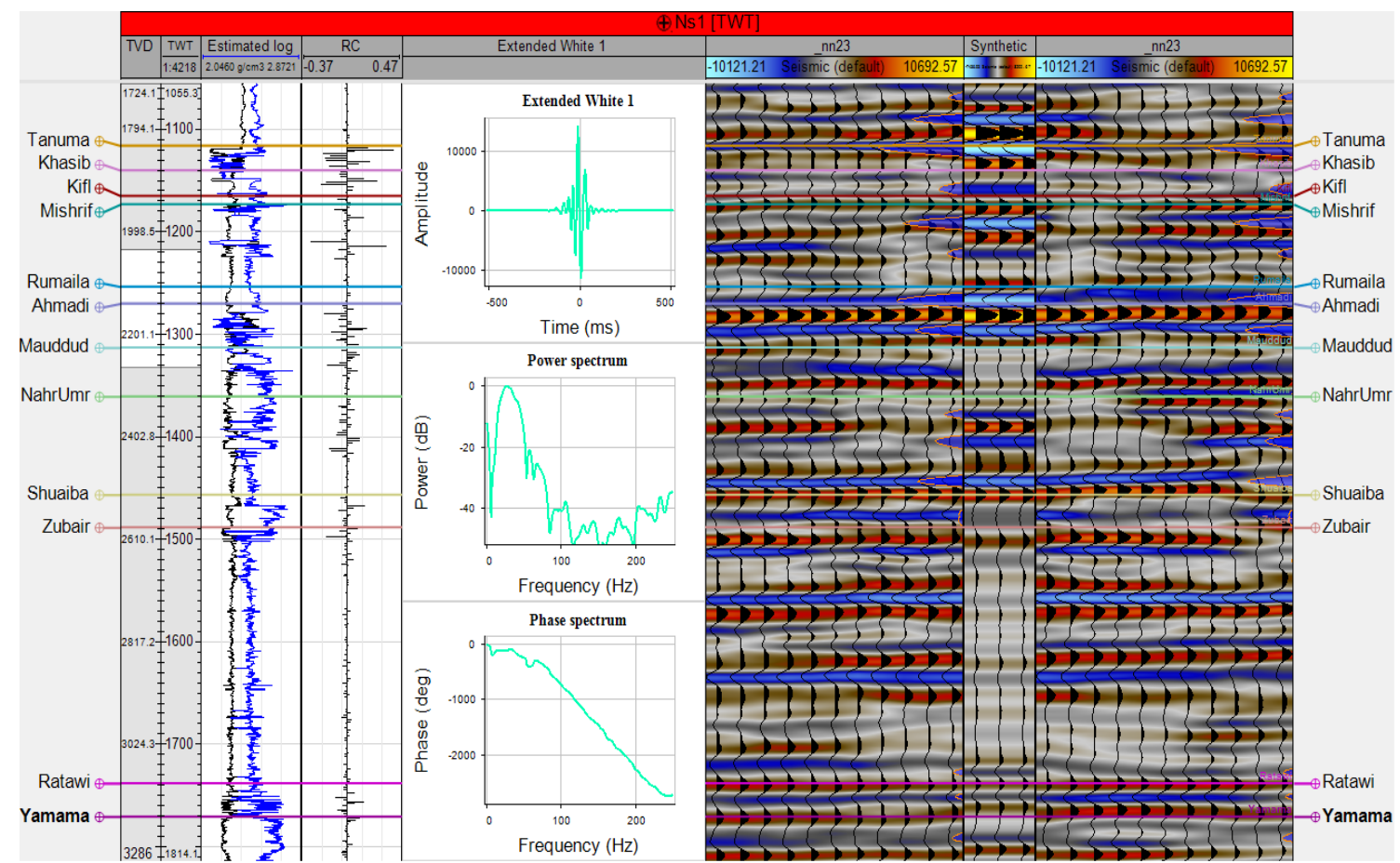

Figure 3- Synthetic generation of well Ns1.

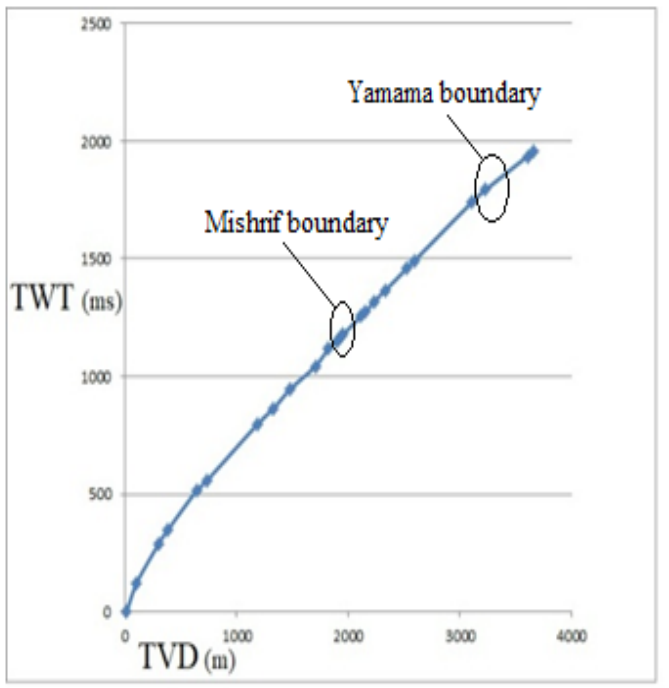

Figure 4-Checkshot survey of well Ns1.

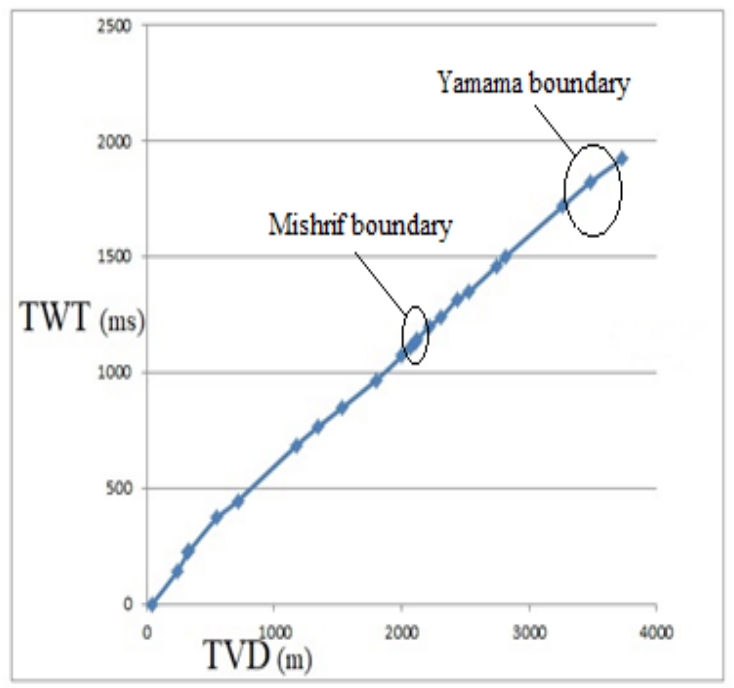

Figure 5- Checkshot survey of well Subba 8.

\section{Horizon picking}

Picking is marking the reflection on a seismic section. It involves deciding what wiggles from a trace to trace are from the same reflection, that is, which wiggles were reflected from the same rock layer[13]. The most important process in seismic interpretation work is the horizon picking. The more accurate in picking horizons leads to more accurate of results. The continuity and the quality of the picked reflectors which are labeled on seismic section were good to intermediate for both Mishrif and Yamama Formations as shown in Figure-6.

\section{Two-Way Time Maps}

The two picked horizons of top Mishrif and top Yamama Formations are used to construct the twoway time maps, using Petrel software (Figure- 7 and 8).The figures of the two reflectors show that TWT increases towards NE direction and decreases in SW direction of the area. The TWT map of the top Mishrif (Figure- 7) shows enclosure noses structure in NE boundary of the studied area and some small noses in the south-east part of the area. These enclouser noses are sill exist in TWT map of top 
Yamama in NW of the area while some noses are appear clearly in TWT value of $1800 \mathrm{~ms}$ and 2000 $\mathrm{ms}$ in south and north-east parts of the area. These noses may represent structural features.

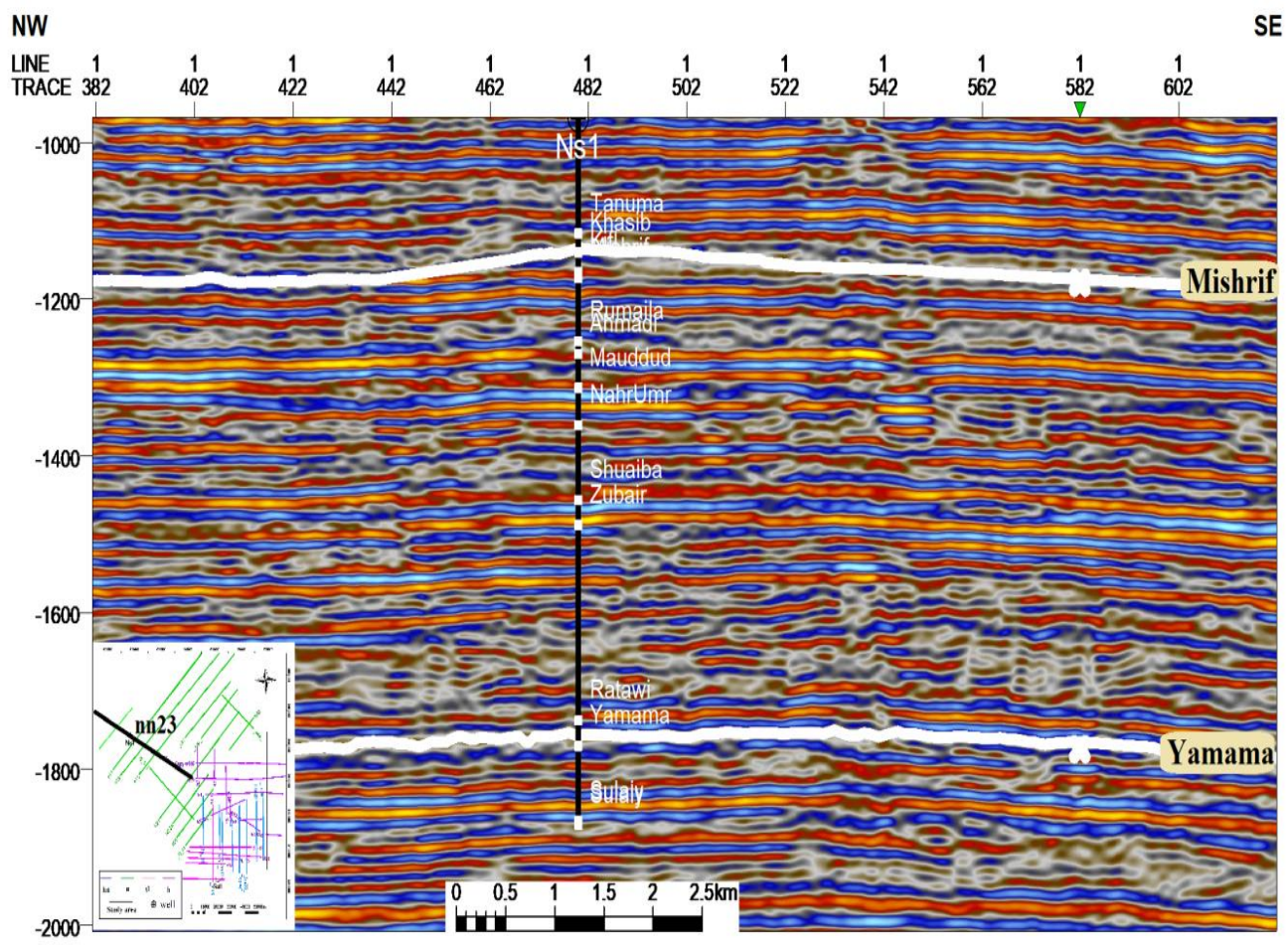

Figure 6-The seismic section that passing through the well Ns-1

\section{Depth Maps}

There are many ways to convert time maps into depth maps, and one of the most important of these methods is the velocity model method, which was used in this study to construct depth maps from sea level datum to the tops of Mishrif and Yamama Formations.

Figure-9 represents top Mishrif Formation depth map. The higher depth is in the north eastern part of the area which reach to about $2750 \mathrm{~m}$ depth may represent a structural feature as syncline (enclousures).There is structure (nose) in East of the study area. The area trending NE-SW which means that slope of the reflector is towards the NE.

The same trend (NE-SW) of the depth map of top Yamama (Figure- 10) from about 2225m in the west to about $4200 \mathrm{~m}$ in NE of the area. Some structural features are shown in the N, NE and W of the area at this reflector. 


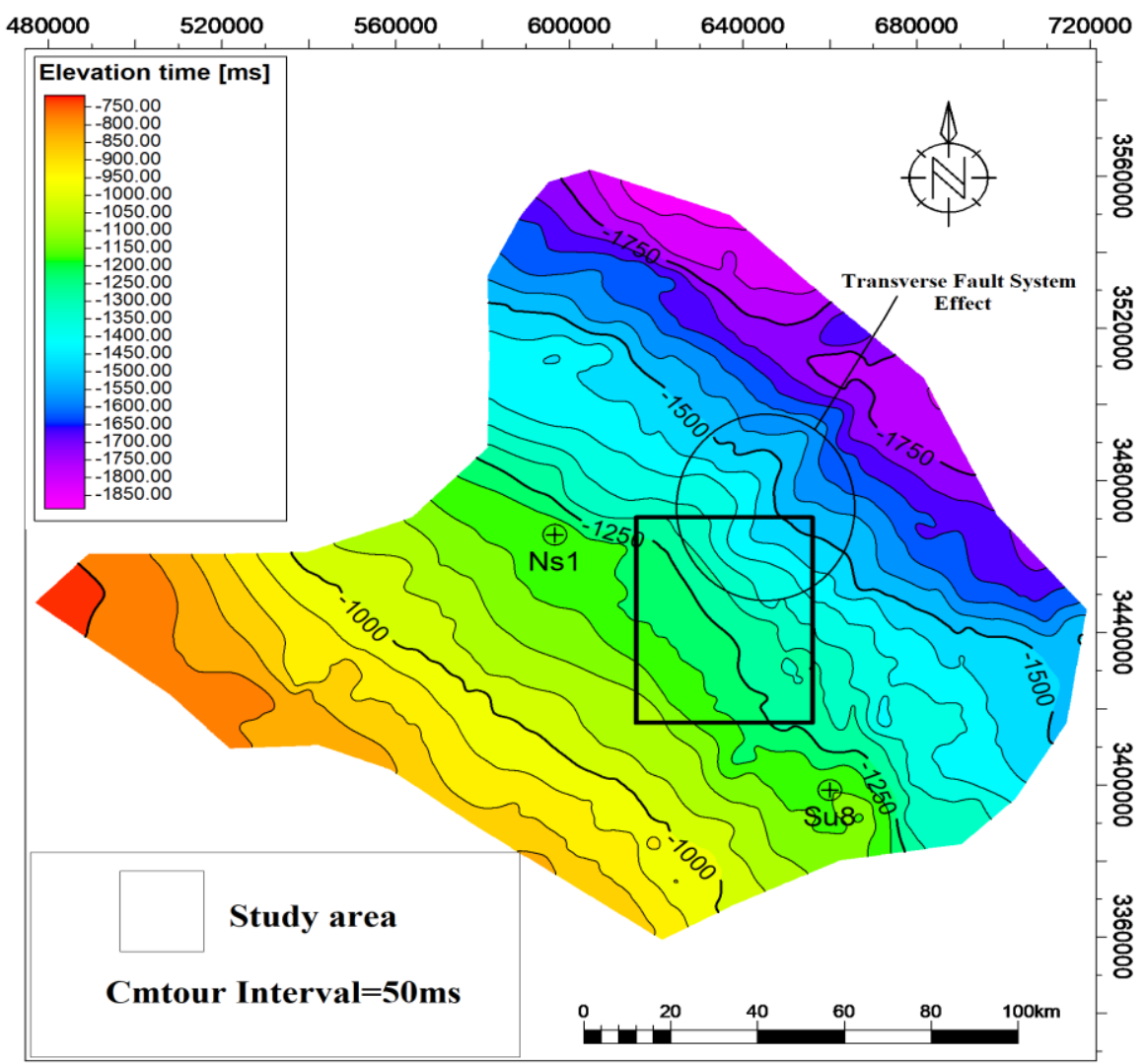

Figure 7- Top Mishrif TWT map.

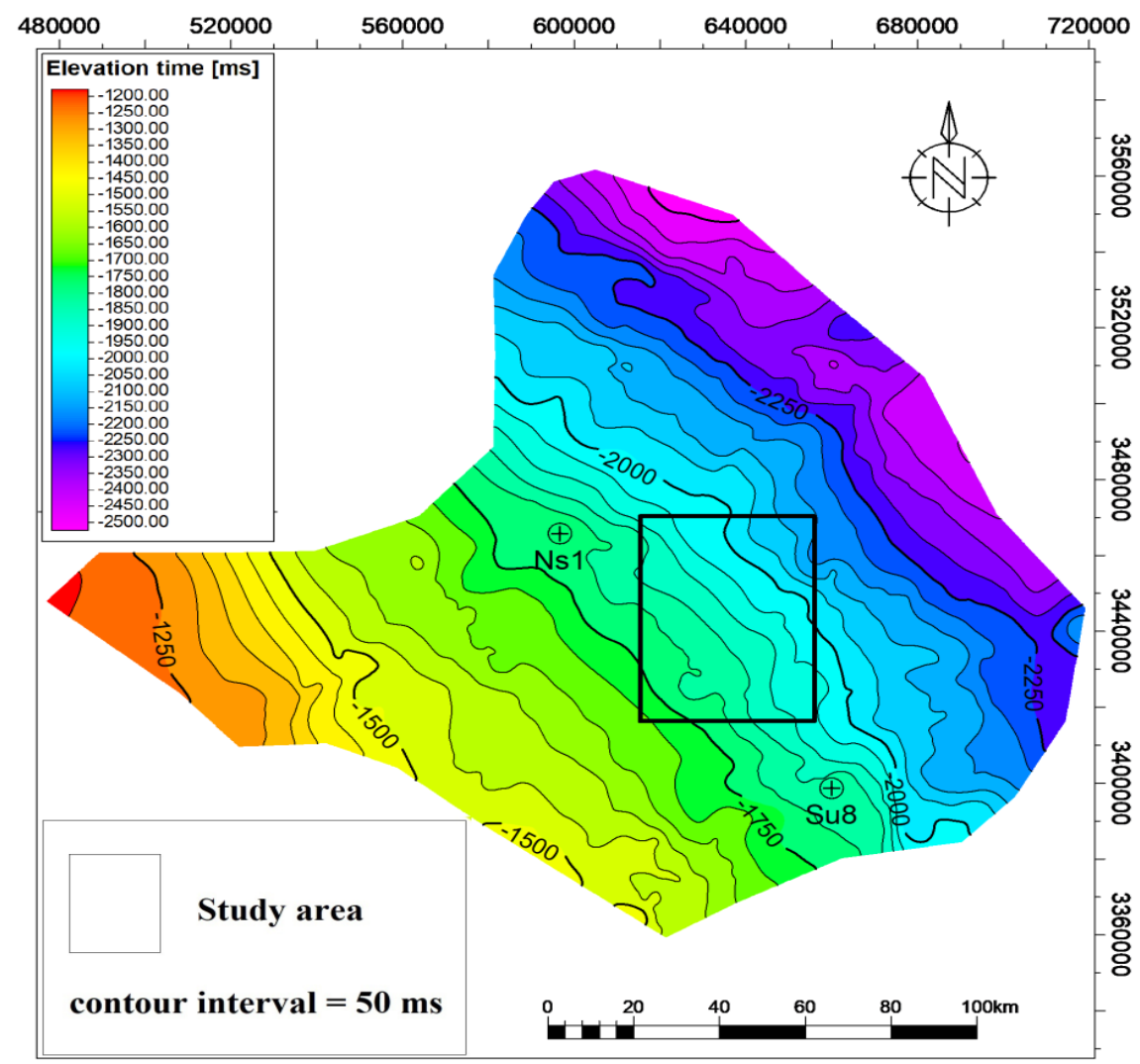

Figure 8-Top Yamama TWT map. 


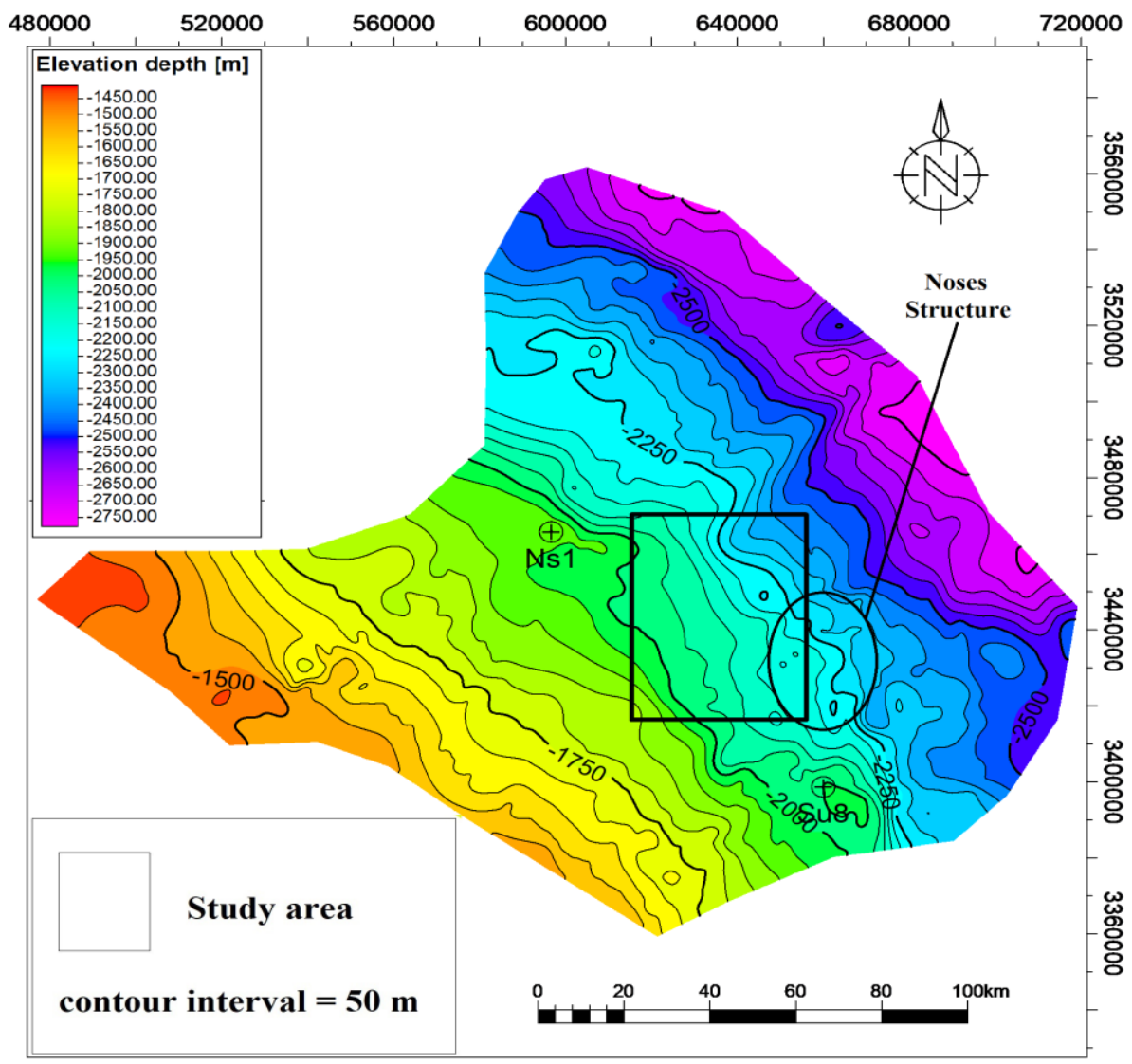

Figure 9-Top Mishrif depth map.

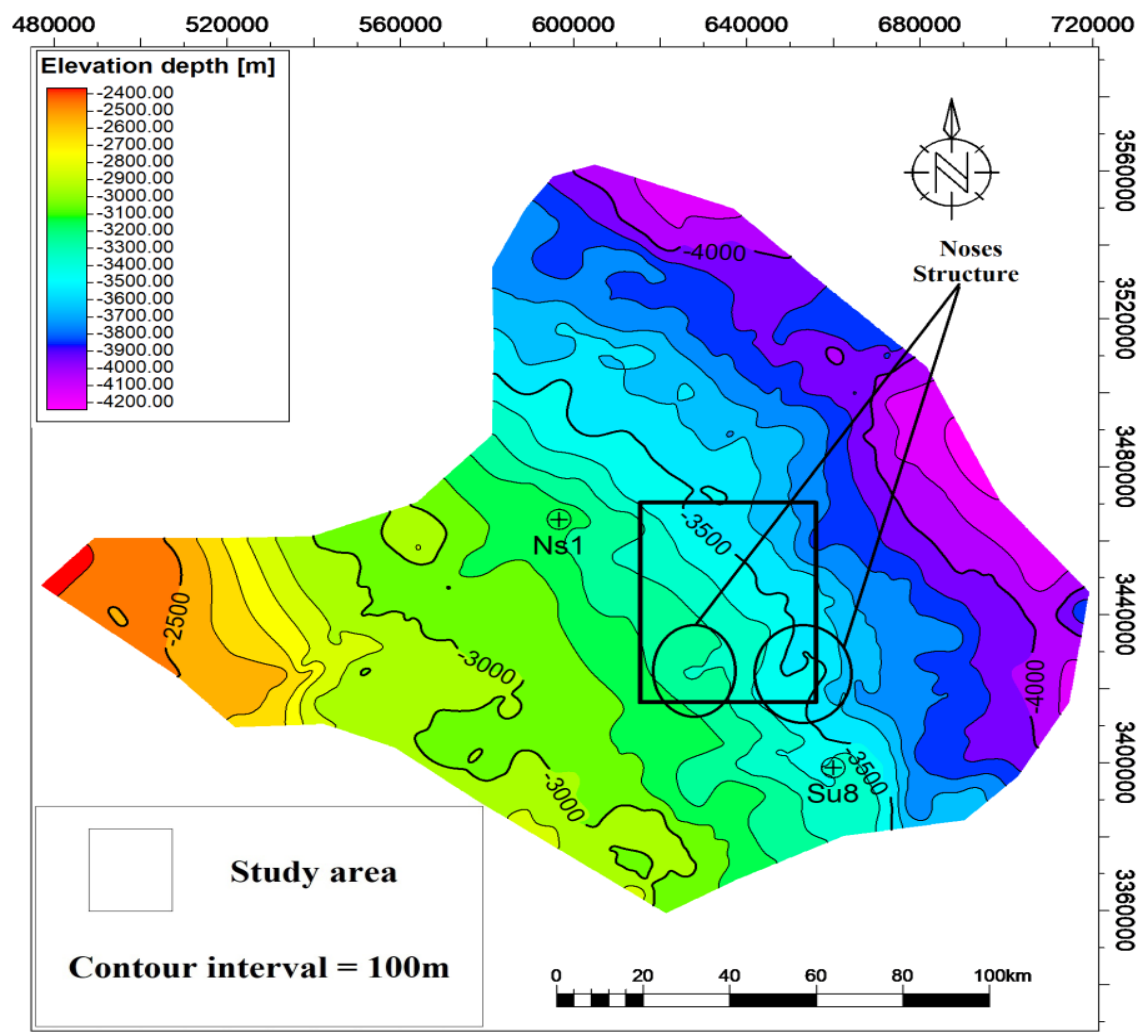

Figure 10-Top Yamama depth map. 


\section{Seismic Attribute Sections}

The seismic attributes extraction and their analysis are used to make the seismic image more obvious. Seismic attributes technique has been used to support the interpretation of the seismic section in current study to indicate the direct hydrocarbon indicators. The used attribute sections are:

\section{1-Instantaneous phase}

The instantaneous phase is a seismic attribute used to depiction of the phase angle at any moment along a trace independent amplitude. It exposes powerless and strong events with equal strength to recognize many straigraphical and stutrucal features [14]. The information of instantaneous phase is very important in showing and distinguishing the ends of continuity of reflective[15].

In the instantaneous phase section of the study area, seismic reflection mound configuration was recorded in the studied horizon (Figure-11), which is the same as the behavior found and extended in the Nasiriya oil field near Well Ns1. The presence of such features (mounds) refers to the direct hydrocarbon indicator (DHI) near the middle of the study area and may indicate the accumulation of hydrocarbons.

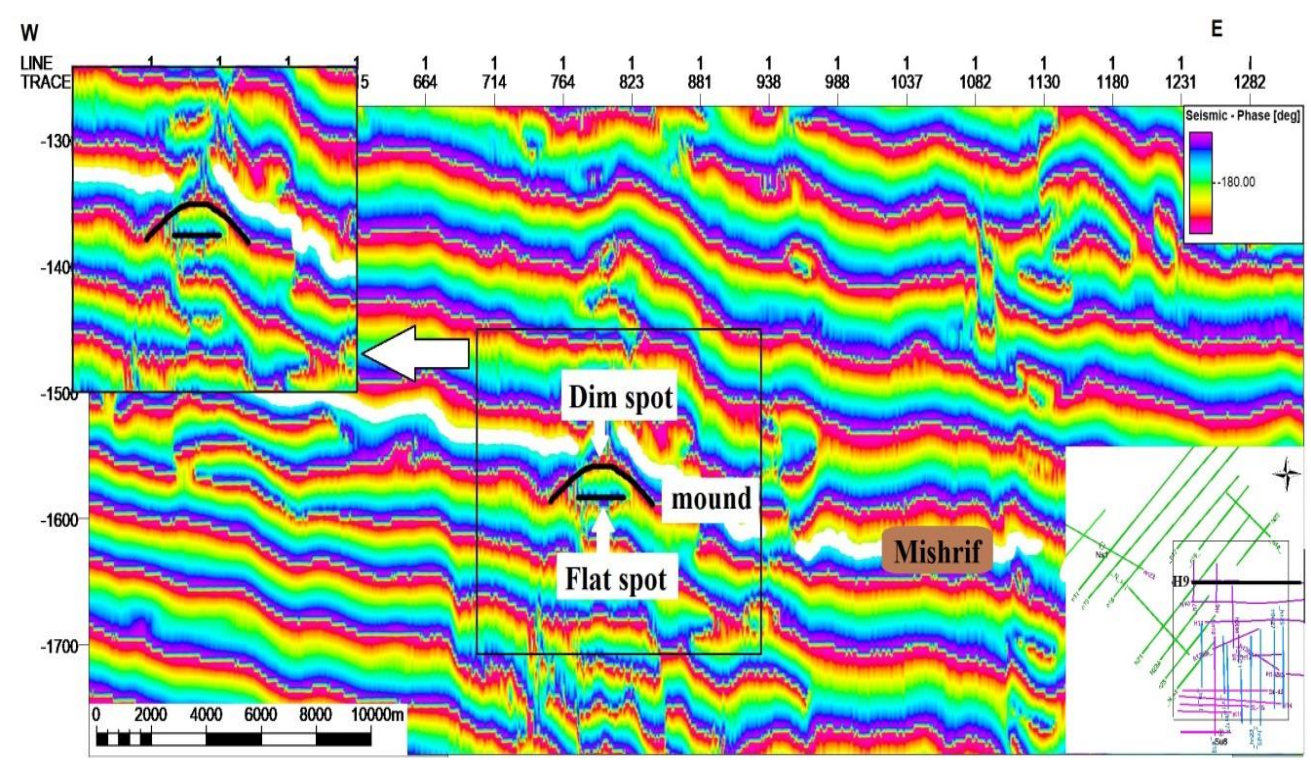

Figure 11- Mound, Dim spot and Flat spot in instantaneous phase section of H9.

\section{2-Relative acoustic impedance:}

The relative acoustic impedance is the sum of the amplitude values of the regular samples. Integrate the seismic traces and then pass the results through a high-pass Butterworth filter to reduce the low frequency noise that may be introduced [16]. Relative acoustic impedance attribute are performed by petrel software for seismic section H5 which shown in (Figure- 12). Low amplitude values is recognized in the study area which indicates most likely, areas of organic compound accumulation. 


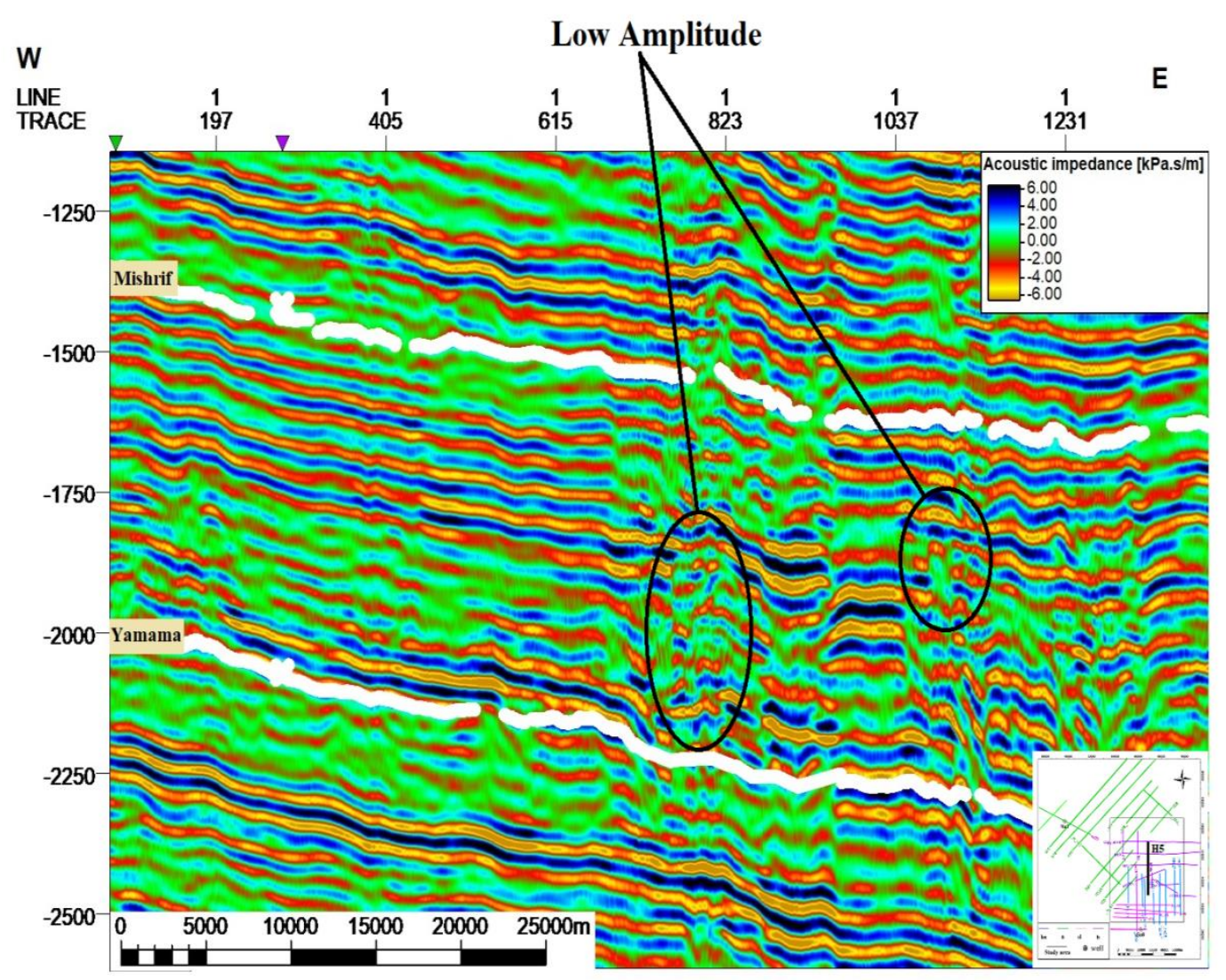

Figure 12- Relative acoustic impedance section of H5line.

\section{Conclusions}

The study concluded that the slope trending of the study area is NE-SW and depth map of the top Mishrif reflector showed that the depth increases to the North East $(3000 \mathrm{~m})$ and decreasing towards the west of the study area $(1450 \mathrm{~m})$ and depth map of the top Yamama Formation reflector showed that the depth increases to the North East $(4200 \mathrm{~m})$ and decreasing towards the west of the study area $(2400 \mathrm{~m})$.

Some enclosures and noses are recognized in the northern parts of the study area and western part extending in both Mishrif Formation and Yamama Formation. These features may represents a hydrocarbon accumulation traps.

The instantaneous phase section shows the mound, dim spot and flat spot features which represent direct hydrocarbon indicators for probably presence of hydrocarbon reservoir in study area.

\section{References}

1. Hart, Bruce S., 2004. Principle of $2 D$ and $3 D$ seismic interpretation, McGill University, 443p.

2. Al-Sadi, H. N., 2017, Seismic hydrocarbon exploration: $2 D$ and $3 D$ Techniques, springer international publishing, Switzerland, 331P.

3. Kearey, P., Brooks, M., \& Hill, I. 2002. An Introduction to Geophysical Exploration (3d ed.). Balckwell science, 510p.

4. Aqrawi, A.A.M., Goff, J.C., Horbury, A.D., and Sadooni, F.N., 2010: The petroleum geology of Iraq published by scientific press Ltd, 27p.

5. State Establishment of Geological Survey and Mining (GEOSURV), 1990. Geological Map of Iraq, printed and published by the GEOSURV, Baghdad, Iraq. (in Arabic).

6. State Establishment of Geological Survey and Mining (GEOSURV), 1996, Tectonic Map of Iraq, printed and published by the GEOSURV, Baghdad, Iraq (in Arabic).

7. Jassim, S. Z., \& Goff, J. C. 2006. Geology of Iraq (1st ed.). Prague. Czech: Dolin, Prague and Moravian Museum, Brno, p470. 
8. Al-Khadimi, J. A., Sissakian, V. K., Fattah, A. S., and Deikaran, D. B., (1996), Tectonic map of Iraq, (Scale: 1:1 000 000) S. E. of Geological Survey and Mining, Iraq, p10.

9. 9-Sherwani, G. H., 1983 Depositional environment and stratigraphic relationship of Mishrif formation in selected boreholes, southern and middle Iraq. M.sc Thesis, university of Baghdad (in Arabic).

10. Buday, T.and Jassim, S.Z., 1984 .Geological map of Iraq 1:1,000,000 scale Series, sheet No.2,Tectonic Map of Iraq.Publication of GEOSURV,Baghdad.

11. Sadooni, F. N., 1993. Stratigraphic Sequence, Microfacies and Petroleum Prospects of the Yamama Formation, Lower Cretaceous, Southern Iraq. AAPG Bull, 77: 1971-1988 .

12. Buday, T. 1980. The Regional Geology of Iraq; Strtigraphy and Paleogeography. Baghdad: Geoserv, p12.

13. Yousif H. M. and Al-Ridha N. A. 2019. Seismic structural study of Mishrif and Nahr Umr Formations in Huwaiza oilfield south-eastern Iraq. Iraqi Journal of Science, 60(3): 554-567.

14. Sheriff, R. E., 2002. Encyclopedic Dictionary of Applied Geophysics, 4th Ed., SEG, 13 GEOPHYSICAL REFERENCES SEIREIS, 429p.

15. Khorshid S. Z. and Kadhm A.D. 2015. Subsurface Investigation of Oligocene Geologic Formations Age, East Baghdad Oil Field .Iraqi Journal of Science, 56(4C): 3441-3451.

16. Schlumberger. 2016. Petrel: Generating $3 D$ seismic cube from $2 D$ seismic sections. Unpublished report, p12. 